\title{
Surgical Management of Advanced and Metastatic Renal Cell Carcinoma: A Multidisciplinary Approach
}

\author{
Brian M. Shinder ${ }^{1}$, Kevin Rhee ${ }^{1}$, Douglas Farrell', Nicholas J. Farber', Mark N. Stein ${ }^{2}$, \\ Thomas L. Jang ${ }^{1}$ and Eric A. Singer ${ }^{1 *}$ \\ 'Section of Urologic Oncology, Rutgers Cancer Institute of New Jersey and Rutgers Robert Wood Johnson Medical School, \\ New Brunswick, NJ, United States, ${ }^{2}$ Division of Medical Oncology, Rutgers Cancer Institute of New Jersey and Rutgers \\ Robert Wood Johnson Medical School, New Brunswick, NJ, United States
}

\section{OPEN ACCESS}

Edited by:

Scott T. Tagawa,

Weill Cornell Medical

College, United States

Reviewed by: Won Kim,

University of California at San Francisco, United States

Takeshi Yuasa,

Japanese Foundation for

Cancer Research, Japan

Jaspreet Singh Batra,

Weill Cornell Medical College, United States

*Correspondence: Eric A. Singer eric.singer@rutgers.edu

Specialty section: This article was submitted to Genitourinary Oncology, a section of the journa Frontiers in Oncology

Received: 02 February 2017 Accepted: 08 May 2017 Published: 31 May 2017

Citation:

Shinder BM, Rhee K, Farrell D, Farber NJ, Stein MN, Jang TL and Singer EA (2017) Surgical

Management of Advanced and Metastatic Renal Cell Carcinoma: A Multidisciplinary Approach.

Front. Oncol. 7:107. doi: 10.3389/fonc.2017.00107
The past decade has seen a rapid proliferation in the number and types of systemic therapies available for renal cell carcinoma. However, surgery remains an integral component of the therapeutic armamentarium for advanced and metastatic kidney cancer. Cytoreductive surgery followed by adjuvant cytokine-based immunotherapy (predominantly high-dose interleukin 2) has largely given way to systemic-targeted therapies. Metastasectomy also has a role in carefully selected patients. Additionally, neoadjuvant systemic therapy may increase the feasibility of resecting the primary tumor, which may be beneficial for patients with locally advanced or metastatic disease. Several prospective trials examining the role of adjuvant therapy are underway. Lastly, the first immune checkpoint inhibitor was approved for metastatic renal cell carcinoma (mRCC) in 2015, providing a new treatment mechanism and new opportunities for combining systemic therapy with surgery. This review discusses current and historical literature regarding the surgical management of patients with advanced and mRCC and explores approaches for optimizing patient selection.

Keywords: renal cell carcinoma, targeted therapy, cytoreductive nephrectomy, cytoreductive partial nephrectomy, lymphadenectomy, neoadjuvant, metastasectomy

\section{INTRODUCTION}

Renal cell carcinoma (RCC) remains one of the most commonly diagnosed cancers in the United States, with 63,990 new cases and 14,400 deaths expected in 2017 (1). The majority of patients will present with organ-confined disease (2), and surgical resection of these tumors generally results in excellent long-term disease-free survival (DFS) (3). However, for patients with advanced or metastatic disease, survival rates are poor $(4,5)$. Approximately $20-30 \%$ of men and women with RCC present with metastatic disease, while $20-40 \%$ of those who undergo surgical resection for localized RCC will develop metastases, making this disease state a considerable challenge $(6,7)$.

Despite recent advances in systemic therapies, surgery remains an integral component in the treatment algorithm for aggressive disease phenotypes. In this review, we discuss the role of surgery in the overall management of locally advanced and metastatic renal cell carcinoma (mRCC). 


\section{CYTOREDUCTIVE NEPHRECTOMY IN THE CYTOKINE ERA}

Cytoreductivenephrectomy $(\mathrm{CN})$ is defined as the surgical removal of the primary renal tumor in the setting of mRCC. During the initial years of the cytokine era, controversy existed as to whether $\mathrm{CN}$ had any clinical benefit. Several early retrospective studies demonstrated an improved response to immunotherapy in patients undergoing debulking surgery compared with patients treated with cytokines alone $(8,9)$. Eventually, landmark Level 1 evidence supporting $\mathrm{CN}$ plus cytokine therapy with IFN- $\alpha$ in advanced RCC was established by the results of two prospective phase 3 randomized controlled trials: SWOG-8949 (Southwest Oncology Group) (10) and EORTC-3047 (European Organization for Research and Treatment of Cancer) (11). Both the SWOG and EORTC trials demonstrated a significant overall survival (OS) advantage and improved progression-free survival (PFS) in patients who underwent $\mathrm{CN}$ prior to cytokine therapy versus patients undergoing immunotherapy alone with $\operatorname{IFN}-\alpha(10,11)$. The SWOG trial evaluated 241 patients and showed a 3-month OS benefit in the nephrectomy group versus non-nephrectomy group (11.1 vs. 8.1 months, respectively) (10). A subsequent update of the SWOG data with 9-year follow-up again favored $\mathrm{CN}$ by showing a 3-month OS benefit in the nephrectomy group and a $26 \%$ reduction in death (12). Likewise, the EORTC study showed an even greater benefit in patients undergoing $\mathrm{CN}$ followed by IFN- $\alpha$ versus IFN- $\alpha$ alone. Time to progression [ 5 vs. 3 months, hazard ratio (HR) 0.60 ; 95\% CI, 0.31-0.94; $p=0.04$ ], and median duration of survival (17 vs. 7 months, HR $0.54 ; 95 \%$ CI, $0.36-0.97 ; p=0.03$ ) were significantly better in the patients who underwent $\mathrm{CN}$ (11). Importantly, $\mathrm{CN}$ was concluded to be safe, as both studies showed a very low perioperative mortality rate of less than 1\%. A meta-analysis of the SWOG and EORTC data showed an OS of 13.6 months among patients who underwent $\mathrm{CN}$ plus IFN- $\alpha$ vs. 7.8 months for IFN- $\alpha$ alone, representing a $31 \%$ relative risk reduction in risk of death. Also, $95 \%$ of patients in combined analysis of the SWOG and EORTC data were able to receive IFN- $\alpha$ after surgery (median 19 days later) (13). Furthermore, an analysis of 5,372 people with mRCC from the Surveillance Epidemiology and End Results Program (SEER) database demonstrated a significant survival benefit of $\mathrm{CN}$, with a 10 -year OS of 12.7 versus $1.2 \%$ for those without surgery (14). As a result of these analyses, the role of $\mathrm{CN}$ was established as standard therapy for patients with mRCC in the cytokine era.

\section{CN IN THE TARGETED THERAPY ERA}

In the past decade, the systemic management of mRCC has changed significantly, as our understanding of the molecular biology of RCC has increased (15). Multiple-targeted therapies (TTs) that primarily inhibit VEGF (sunitinib, sorafenib, axitinib, bevacizumab, cabozantinib, lenvatanib) and mTOR pathways (temsirolimus, everolimus) have been approved for the management of mRCC (Table 1) (16). In light of the efficacy of TT agents, the utility of nephrectomy in patients with mRCC has been questioned. In fact, recent reports indicate declining utilization rates of CN in the TT era $(17,18)$. An analysis of the SEER database by Tsao et al. showed that the rate of $\mathrm{CN}$ performed was about $50 \%$ in patients with stage IV RCC until 2005, when TTs were approved by the FDA. There was then a steady decrease to $38 \%$ in 2008 , possibly due to the yet unknown interaction between CN and TT and an unwillingness to subject patients to the morbidity of surgery given the benefits of TT (19). Currently, evidence supporting the role of $\mathrm{CN}$ in the TT era for the management of mRCC remains limited and is primarily based on retrospective series and administrative databases.

Choueiri et al. (32) reported on 314 patients with mRCC treated with adjuvant anti-VEGF-targeted agents and concluded that those who previously underwent $\mathrm{CN}$ lived a median of 10 months longer (19.8 vs. 9.4 months, HR $0.44 ; 95 \%$ CI 0.32 , $0.59 ; p<0.01)$. Although patients who underwent $\mathrm{CN}$ had fewer negative predictors of survival (lower corrected serum calcium levels and a better Karnofsky performance status), when controlled for known prognostic factors, $\mathrm{CN}$ still demonstrated a significant OS benefit (HR 0.68, $p=0.04$ ) (32).

Heng et al. used the International Metastatic Renal Cell Carcinoma Database Consortium (IMDC) to identify patients with synchronous mRCC treated with adjuvant-targeted therapy

TABLE 1 | FDA-approved therapies for renal cell carcinoma with their pivotal trial parameters.

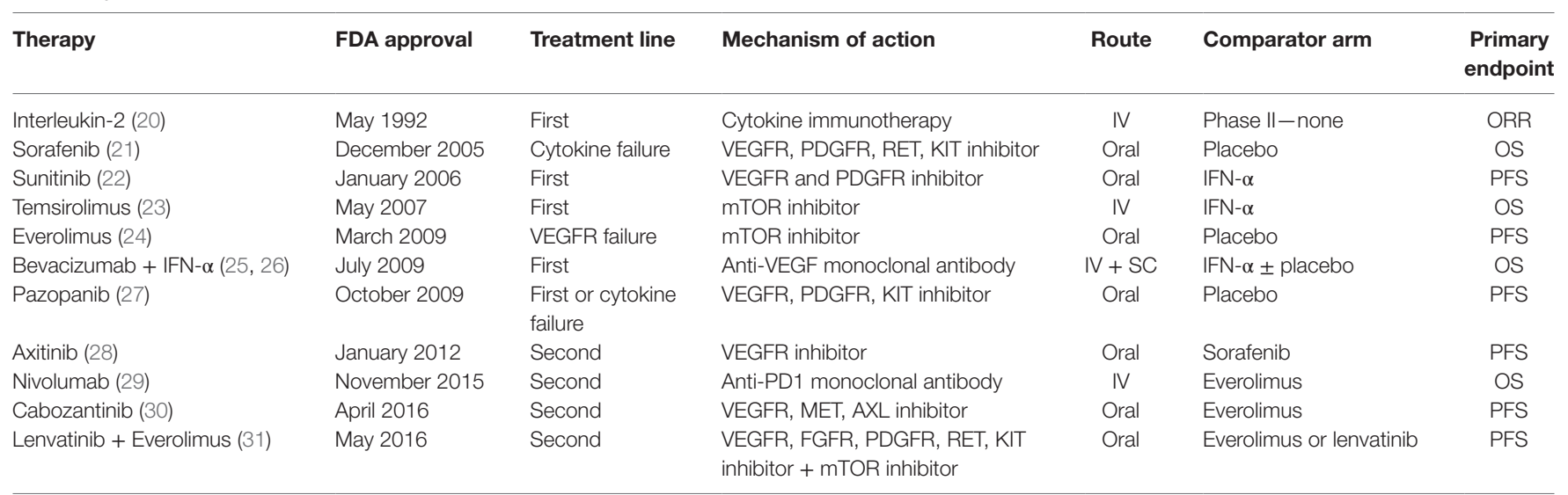

Modified with permission from Modi et al. (16). 
at the population-based level and examined survival in this group. Of 1,658 patients, 982 (59.2\%) underwent CN. OS was significantly higher than in those undergoing surgery (20.6 vs. 9.5 months, $p<0.01$ ), and, after adjusting for prognostic risk factors, patients undergoing nephrectomy had a $40 \%$ decreased risk of death (HR 0.60, 95\% CI 0.52, 0.69; $p<0.0001$ ) (33).

Similarly, Hanna et al. (34) recently reported on 15,390 patients diagnosed with primary mRCC from the National Cancer Database (NCDB) treated with at least one TT, 5,374 (35\%) of whom also underwent CN. The median time to death was significantly longer in the $\mathrm{CN}$ group versus those who did not undergo surgery (17.1 vs. 7.7 months, respectively; $p<0.001$ ), and the 3-year OS rates were $62.7 \%$ for those who underwent $\mathrm{CN}$ and just $9.8 \%$ in the non-CN group. Additionally, after adjusting for various covariates such as age, Charlson Comorbidity Index (CCI), T stage, and other factors, multivariate Cox regression analysis revealed CN patients had a lower risk of death (HR 0.49, $p<0.001)$. Finally, a recent meta-analysis that included 39,953 patients across 12 studies found a reduced risk of death (HR, 0.46; CI, $0.32-0.64 ; p<0.01$ ) for patients who were treated with $\mathrm{CN}$ and TT compared to just TT alone (35).

Despite this evidence, careful patient selection remains critical. Mathieu and colleagues found in their cohort of 351 patients with mRCC that the benefit of $\mathrm{CN}$ in combination with adjuvant TT was lost when examining patients with poor performance status (36). Among the entire cohort, median OS was significantly greater for those who underwent $\mathrm{CN}$ and TT versus TT alone (38.1 vs. 16.4 months, $p<0.001$, respectively). For patients with an ECOG score of 2 or 3, however, this significance was lost. Furthermore, there was no difference in survival for patients with poor MSKCC risk scores. This is congruent with the subgroup analysis in the study by Choueiri et al. described above, where patients with a poor Karnofsky performance status $(<80 \%)$ did not have an improved OS $(p=0.08)$. These results suggest that while CN may be favorable in the mRCC setting, patients who have other significant comorbid conditions, harbor brain or bone metastases, have a high burden of disease outside of the kidney, or a poor performance status might be better served by immediate systemic therapy instead of $\mathrm{CN}$. These findings also illustrate the importance of proper $\mathrm{CN}$ patient selection.

\section{CN PATIENT SELECTION}

Cytoreductive nephrectomy can be a challenging operation with significant potential morbidity, especially in older patients, and has been associated with increased complication and perioperative mortality rates $(37,38)$. Using the SEER database, Cloutier et al. (39) demonstrated a 30 -day mortality of $4.2 \%$ in mRCC patients (all T stages) compared with just 0.3 and $1.3 \%$ for patients with $\mathrm{T}_{1-2} \mathrm{~N}_{0} \mathrm{M}_{0}$ and $\mathrm{T}_{3-4} \mathrm{~N}_{0-2} \mathrm{M}_{0}$ disease, respectively, for those who underwent partial or radical nephrectomy. However, this rate reached $10.5 \%$ in the subset of patients aged 80 years or older. Similarly, Sun et al. (40) confirmed that elderly patients ( $>75$ years) were 2.2 -fold more likely to experience perioperative mortality than younger patients ( $<75$ years) ( 4.8 vs. $1.9 \%$, $p<0.001$ ). Thus, accurately identifying patients who stand to benefit from the operation is imperative.
Early retrospective studies on $\mathrm{CN}$ reported an overall mortality rate of up to $2.5 \%$, with up to $40 \%$ of patients being unable to subsequently receive systemic cytokine therapy for a variety of reasons, mainly perioperative complications, perioperative death, or tumor progression during the postoperative period $(41,42)$. Likewise, Bennett and colleagues evaluated 30 patients with stage IV RCC and found 23 (77\%) were unable to receive systemic cytokine therapy after $\mathrm{CN}$ due to either perioperative death, cardiovascular insufficiency, rapid disease progression during the postoperative period, prolonged surgical morbidities, compromised renal function, or mental distress (43). The results of the original SWOG and EORTC trials themselves demonstrated that up to $25 \%$ of patients in both groups progressed rapidly and died within 4 months, suggesting that a significant proportion of patients may not benefit from surgery $(10,11)$. It is clear that the morbidity associated with $\mathrm{CN}$ should not be considered negligible, and great effort should be made to define the optimal profile of patients for surgery.

As the oncologic course of patients with mRCC can vary considerably, several predictive models for patients who may benefit from $\mathrm{CN}$ have been developed. Fallick and colleagues (41) developed several criteria for patient selection for CN: (1) tumor debulking representing greater than $75 \%$ of the total tumor burden; (2) no central nervous system, bone, or liver metastases; (3) predominantly clear cell histology; (4) adequate pulmonary and cardiac function; and (5) ECOG performance status of 0 or 1. However, other reports have demonstrated that the presence of bone metastases is not a relative contraindication to $\mathrm{CN}$ unless the patient has a significant burden of disease and that patients with non-clear cell histology may still benefit from CN (44). Furthermore, these studies investigated patients who received IFN- $\alpha$, making its utility in the current TT era unknown.

To evaluate factors influencing survival among patients undergoing $\mathrm{CN}$ in the TT era, Culp et al. (45) retrospectively analyzed 566 patients who underwent $\mathrm{CN}$ in comparison to 110 patients receiving targeted therapy alone. Multiple clinical parameters were compared between those surviving $<8.5$ months (which was defined as no benefit from $\mathrm{CN}$ ), and those surviving longer. The authors identified 7 seven variables that were significantly associated with a shorter survival: serum albumin below lower limit of normal (LLN), LDH above upper limit of normal (ULN), a clinical tumor classification of T3 or T4, symptoms from a metastatic site, presence of liver metastasis, presence of retroperitoneal adenopathy, and presence of supradiaphragmatic adenopathy. The authors concluded that patients with 3 three or less of these negative predictors might benefit from $\mathrm{CN}$ compared to systemic TT alone (HR, 0.39; 95\% CI, 0.31-0.48; $p<0.001$ ), while those with 4 or more would not benefit from CN (HR, 0.89; 95\% CI, 0.64-1.24; $p=0.499$ ). Although these results are limited by the study's retrospective nature with no external validation, this was the first large-scale analysis of multiple preoperative clinical parameters that may potentially predict outcomes following CN. Following this, Margulis et al. (46) developed a multivariable model to predict cancer cancer-specific survival at 6 and 12 months following CN (46). The preoperative nomogram assigns a point score from 0 to 100 based on a patient's patient's albumin and LDH. This score is then used to predict the 6 and 
12- month risk of death from kidney cancer. Though the model demonstrated good calibration and a discrimination of 0.76 when applied to an internal validation set, further external validation is still required.

In another attempt to identify risk factors that can be used to optimize patient selection for $\mathrm{CN}$, Heng et al. described the use of the IMDC criteria for selecting patients who would benefit from $\mathrm{CN}$. These criteria are the six preoperative risk factors of Karnofsky performance score $<80$, hemoglobin < LLN, neutrophils > ULN, platelets > ULN, diagnosis to targeted therapy $<1$ year, and serum corrected calcium $>$ ULN. Patients who had four, five, and six of these risk factors did not derive any significant benefit from $\mathrm{CN}$ in an analysis of the IMDC database of patients who were treated with $\mathrm{CN}$ and a TT. Additionally, the interaction between the number of IMDC factors patients had and nephrectomy status was statistically significant $p=0.0005$, supporting their use in patient selection (33).

Abel et al. (47) demonstrated the importance of time to maximal response to TT as a measure of predicting eventual oncologic outcomes. Achieving a decrease in primary tumor size of $\geq 10 \%$ was an independent predictor of OS ( $\mathrm{HR}, 0.43, p=0.007)$, while a decrease within the first 60 days of treatment was an even stronger predictor of survival on multivariate analysis (HR, 0.26; $p=0.031$ ). These findings have led many to advocate the use of the initial response to systemic therapy as a "litmus test" to identify patients who could benefit from CN (48).

Pathology-derived predictors have also been evaluated for associations with post-CN survival. Sarcomatoid and non-clear cell histology have consistently been associated with worse survival outcomes $(44,49)$. In one report of 417 patients undergoing CN, 62 patients with sarcomatoid features had a median survival of 4.9 versus 17.7 months for those without these features $(p<0.001)$ (50). Culp et al. (45) also found a HR for survival of $1.4(95 \%$ CI, $1.08-1.80 ; p=0.011)$ for the presence of sarcomatoid features in their analysis of factors affecting survival after CN. However, this same group later demonstrated that percutaneous biopsy of a primary renal mass was only able to identify sarcomatoid features in $12 \%$ of tumors later found to have such features after nephrectomy, suggesting it has only marginal utility to guide preoperative clinical decision making (51).

Patients with non-clear cell mRCC have frequently been shown to have worse survival outcomes after CN compared to those with clear cell histology. Kassouf et al. (44) reported significantly worse survival for 92 patients with non-clear cell mRCC compared to 514 patients with clear cell histology: 9.7 versus 20.3 months, respectively ( $p=0.003$ ). Patients with non-clear cell $\mathrm{mRCC}$ had a higher rate of sarcomatoid features (23 vs. $13 \%$, $p=0.026$ ), but even patients with non-clear cell mRCC without sarcomatoid features had shorter survival of 14 months compared to 23.1 months for patients with clear cell RCC with sarcomatoid features $(p=0.017)$. It is unclear whether this is because of nonclear cell mRCC's lack of response to cytokine therapy or more aggressive biology (52). Non-clear cell mRCC also has shown a poorer response to TT compared to clear cell mRCC (53).

The tumor burden of RCC has previously been shown to be predictive of overall and PFS (54). In light of this, the percentage of tumor burden removed by nephrectomy, classically termed fractional percentage of tumor volume (FPTV), may provide a relatively easy way to estimate the survival benefit of $\mathrm{CN}$. Recent reports suggest a threshold of $>90 \%$ FPTV to achieve improved PFS and OS. For instance, Pierorazio et al. (55) described 55 patients undergoing $\mathrm{CN}$ with or without metastasectomy, of which 45 had $>90 \%$ FPTV removed. The patients with a FPTV removal of $>90 \%$ had improved DSS (HR 0.29, $p=0.02$ ) on multivariate analysis when controlling for volume of metastatic disease and multifocal lesions. Similarly, Barbestefano et al. (56) demonstrated a shorter PFS for patients with FPTV removal of $<90 \%$ in a series of 46 patients with clear cell RCC followed by targeted therapy. No patients in this study were reported to have undergone metastasectomy. The $15 \%$ of patients with FPTV removal of $<90 \%$ had a higher risk of disease progression (HR $4.8, p<0.001)$ on multivariate analysis that controlled for known predictive variables.

\section{CYTOREDUCTIVE PARTIAL NEPHRECTOMY}

Partial nephrectomy, or nephron-sparing surgery (NSS), is considered the treatment of choice for localized small renal masses, with oncological outcomes comparable to RN in the management of RCC (57). As preoperative renal dysfunction is present in a substantial number of patients with RCC, and radical nephrectomy has been shown to increase the risk for chronic kidney disease (CKD), surgical approaches that maximize postoperative renal function should be considered (58). There is considerable evidence in the literature that the tumor characteristics, rather than surgical approach, determine CSS and OS (59, 60). For example, Margulis et al. (61) compared the oncological efficacy of partial nephrectomy versus radical nephrectomy in patients with locally advanced $\mathrm{pT}_{2}-\mathrm{T}_{3 \mathrm{~b}} \mathrm{~N}_{0} \mathrm{M}_{0}$ RCC. In this comparison of 34 patients undergoing partial nephrectomy versus 567 patients undergoing radical nephrectomy, CSS was similar between the two surgical approaches (78 vs. $74 \%$, respectively, $p=0.113$ ), though the 5 -year recurrence free survival was improved (82 vs. $62 \%, p<0.012$ ). Moreover, after adjusting for tumor stage, grade, and histology, there were no differences in outcomes.

Although $\mathrm{CN}$ is now considered an integral component of the mRCC treatment algorithm, the role of cytoreductive partial nephrectomy $(\mathrm{CPN})$ in this same disease context is not well established, and the current body of literature supporting its use is limited. In 1996, Krishnamurthi et al. (62) retrospectively reviewed 15 patients who underwent $\mathrm{CPN}$ for $\mathrm{mRCC}$ due to a solitary kidney or CKD. Overall renal function was preserved in 14 out of the 15 patients, as only 1 went on to require hemodialysis. Although this study was limited by its inability to calculate pooled CSS for all the subjects due to the heterogeneity of patient characteristics, burden of metastasis, and adjuvant treatment received, these results nonetheless suggested a potential utility for CPN. Krambeck et al. (63) later reviewed the Mayo Clinic Nephrectomy Registry between 1970 and 2002. Sixteen patients who underwent $\mathrm{CPN}$ for $\mathrm{mRCC}$ with a median follow-up period of 18 months were compared with 404 patients who underwent 
$\mathrm{RN}$ for mRCC. This study demonstrated that survival of patients undergoing CPN was significantly better than those undergoing RN, with 1-, 3-, and 5-year CSS for the CPN group of 81.3, 49.2, and $49.2 \%$, respectively, compared to $50.5,21.1$, and $12.8 \%$, respectively, for the $\mathrm{RN}$ group $(p=0.013)$. One major limitation of this study was that $87.5 \%$ of the patients in the CPN group underwent complete resection of all metastatic sites compared with only $22.5 \%$ from the RN group, which likely biased the final results. In a multi-institutional study, Hutterer et al. (64) reviewed the nephrectomy database of 17 institutions between 1984 and 2001. Of the $777 \mathrm{mRCC}$ patients treated with nephrectomy, $5.8 \%$ had undergone $\mathrm{CPN}$ with a mean follow-up period of 1.8 years. In both a matched and unmatched analysis, a higher, though statistically insignificant, rate of RCC-specific mortality was seen in those who underwent RN.

Capitanio et al. (65) examined the effect of CPN on DSS in comparison to $\mathrm{RN}$ in a population-based study using the SEER registry. From 1988 to 2004, a total of 2,043 patients with metastatic disease underwent $\mathrm{CN}$, with a median follow-up period of 23.5 months. CPN was performed in $2.2 \%$ of the patients and each of the $46 \mathrm{CPN}$ patients were matched with up to four $\mathrm{RN}$ patients for tumor size and race. In this matched population, the 1-, 2-, 5-, and 10-year CSS estimates were 58.8, 44.8, 27.1, and $19.7 \%$, respectively, for $\mathrm{RN}$ patients versus $79.2,60.9,40.2$, and $40.2 \%$ for CPN patients, respectively. This represented a marginally significant association between CPN and CSS (HR 1.78, $p=0.05$ ). Likewise, Hellenthal et al. (66) identified 56,011 RCC patients in the SEER database between 1988 and 2005. Fifteen percent of the patients had metastatic disease at presentation. Of these patients with mRCC, 35\% underwent surgical treatment with only $2.4 \%$ having CPN. On multivariate analysis, it was found that patients undergoing CPN were 0.5 times less likely to die of any cause and 0.48 times likely to die of RCC than those who underwent RN (95\% CI 0.27-0.91, $p<0.024$ and 95\% CI $0.25-0.94, p<0.031$, respectively). Notably, the authors found that tumor size was significantly associated with both overall and cancer-specific survival. This may be partly responsible for the survival benefit seen with CPN, as only $1 \%$ of patients who had a primary tumor size $\geq 7 \mathrm{~cm}$ underwent this surgery.

Even in the absence of high-quality data supporting the use of CPN for patients with mRCC, it could be considered for tumors amenable to such an approach. Established prognostic factors should also be used to assist with patient selection. Additionally, patients for whom $\mathrm{CN}$ is not feasible due to preexisting renal impairment or a solitary kidney can be expected to derive benefit from a nephron-sparing approach, especially in cases in which the primary tumor is small.

\section{ONGOING RANDOMIZED CLINICAL TRIALS ADDRESSING CN}

To prospectively examine the role of $\mathrm{CN}$ in the context of adjuvant-targeted therapy, two large randomized trials are currently ongoing. The Clinical Trial to Assess the Importance of Nephrectomy (CARMENA; NCT00930033) examines nephrectomy followed by sunitinib treatment compared with sunitinib alone in patients with mRCC. This phase III non-inferiority study was initiated in 2009 and enrolls patients with clear cell mRCC and an ECOG performance status of 0 or 1 . The trial has an estimated study completion time of February 2018. Additionally, the EORTC Immediate Surgery or Surgery after Sunitinib Malate in Treating Patients with Metastatic Kidney Cancer (SURTIME; NCT01099423) trial assesses the timing of nephrectomy relative to treatment with sunitinib in patients with resectable mRCC. SURTIME was initiated in 2010 and randomizes patients with mRCC to either a nephrectomy followed by sunitinib or to three courses of sunitinib therapy with subsequent nephrectomy. The primary and secondary endpoints of the SURTIME trial are PFS and OS, respectively.

\section{NEOADJUVANT SYSTEMIC THERAPY FOR MRCC}

Neoadjuvant therapy is frequently used in the treatment of various malignancies to reduce the primary tumor mass and improve the outcome of definitive surgical treatment. In the era of cytokine-based systemic therapy for RCC, there was little role for the neoadjuvant approach. Cytokines such as interleukin-2 and IFN- $\alpha$ were shown to confer an overall increase in survival for patients with metastatic disease, but their benefit in conjunction with surgery or their use in reducing the size of the primary tumor was rarely reported (67). The expansion in the number of TTs and their effects on tumor biology have renewed interest in neoadjuvant treatments for mRCC. Potential benefits of this include improving surgical resectability of the kidney for locally advanced tumors as well as facilitating the ease to which CPN can be performed. Additionally, a lack of response to neoadjuvant therapy may help identify individuals with aggressive disease that would not benefit from nephrectomy, thus avoiding surgical morbidity with little benefit (68).

Powles et al. (69) recently published a report on the use of pazopanib in the neoadjuvant setting for patients with mRCC. A single arm phase II study was conducted that included 104 treatment-naïve patients, although four of these patients could not be analyzed after they dropped out due to treatment related toxicities. Pazopanib was given for $12-14$ weeks prior to $\mathrm{CN}$ and then continued afterward until disease progression. Clinical benefit, or no evidence of disease progression, was seen in $84 \%$ of the patients, though only $63 \%$ of patients underwent surgery. The most common reasons for not undergoing surgery included disease progression $(n=13)$, patient choice $(n=9)$, and inadequate fitness for surgery $(n=5)$. Overall, the median PFS and OS was 7.1 months (95\% CI, 6.0-9.2) and 22.7 months (95\% CI, 14.3-not estimable), respectively (69).

Thomas et al. (70) prospectively evaluated 19 patients with advanced RCC who were deemed unsuitable for surgical intervention due to either locally advanced disease or extensive metastatic burden. Patients received sunitinib (50 mg; 4 weeks on and 2 weeks off) until the primary tumor was determined to be operable, the disease progressed, or there was unacceptable toxicity. No patients experienced a complete response after a median follow-up of 6 months with the median number of cycles 
of sunitinib as 2 . However, 8 patients (42\%) were found to have average primary tumor shrinkage of $24 \%$ (range $2-46 \%$ ). At the time of follow-up, 4 patients (21\%) had undergone nephrectomy, although 5 other patients had died due to disease progression. Interestingly, one of the patients who underwent surgery did not have any reduction in primary tumor size, but rather demonstrated a considerable response in metastatic disease burden, thereby making cytoreductive surgery a reasonable treatment option.

A similar study by Rini et al. (71) investigated 30 patients with unresectable RCC, 19 of which had distant metastases. After receiving a median of three cycles of sunitinib, there was a median decrease of $22 \%$ in the primary tumor size and 13 patients (45\%) were able to undergo surgical resection. Notably, 9 patients were able to have a partial nephrectomy. Only 3 of the patients who were able to have surgery had metastatic disease, suggesting that there may be significant heterogeneity between the primary tumor and metastatic sites. Several other studies have reported on the feasibility of primary tumor downsizing with various neoadjuvant TT, but no single drug appears to be markedly more efficacious than the others. The range of median tumor diameter reduction reported by these studies was 9.5-28.3\% (Table 2) (70-81). These results highlight the important role that neoadjuvant treatment can play in advanced and metastatic RCC and suggest that it should be considered for carefully selected patients with unresectable tumors.

Primary tumor reduction is also of interest to preserve renal function by enabling partial nephrectomy to be performed instead of radical nephrectomy. In order to estimate the volume of kidney that could be preserved by neoadjuvant pazopanib, Rini et al. (80) found a decrease in the R.E.N.A.L. score in $71 \%$ of tumors from 25 patients with locally advanced RCC. This allowed for 6 of 13 NSS ineligible patients to then undergo NSS. Similarly, it was found that more patients became eligible for partial nephrectomy after axitinib treatment, and 14 of 24 patients had an increase in the amount of observers who determined NSS was feasible (84). It should be noted that the ability to perform a partial nephrectomy

TABLE 2 | Results of selected clinical trials evaluating effect of neoadjuvant TT agents on primary tumor size.

\begin{tabular}{lclcc}
\hline Reference & Participants & Drug & $\begin{array}{c}\text { Percent } \\
\text { metastatic } \\
\text { disease }\end{array}$ & $\begin{array}{c}\text { Median } \\
\text { tumor } \\
\text { shrinkage } \\
\text { (\%) }\end{array}$ \\
\hline van der Veldt et al. (72) & 17 & Sunitinib & 100 & 12 \\
Thomas et al. (70) & 19 & Sunitinib & 79 & 24 \\
Cowey et al. (73) & 30 & Sorafenib & 43.3 & 9.6 \\
Hellenthal et al. (74) & 20 & Sunitinib & 20 & 11.8 \\
& & Sunitinib & 42 & 21 (mean) \\
Silberstein et al. (75) & 12 & Sunitinib & 100 & 13 \\
Powles et al. (77) & 66 & Sunitinib & 66 & 22 \\
Rini et al. (71) & 28 & Axitinib & 0 & 28.3 \\
Karam et al. (78) & 23 & Pazopanib & 0 & 26 \\
Rini et al. (80) & 25 & Sunitinib & 40 & 18 \\
Lane et al. (79) & 72 & Sorafenib & 39 & 20.5 \\
Zhang et al. (81) & 18 & Pazopanib & 100 & 14.4 \\
Powles et al. (69) & 100 & (mean)
\end{tabular}

is highly subjective and can differ between surgeons, suggesting the utility of neoadjuvant treatment in facilitating NSS be evaluated on an individual basis. Future studies are needed with stricter criteria for NSS feasibility in order to definitively assess the ability of neoadjuvant therapy to convert RN to NSS.

\section{PERIOPERATIVE SAFETY OF NEOADJUVANT-TARGETED THERAPY}

Historically, there have been concerns of the risks that neoadjuvant treatment with TTs pose in the perioperative setting. However, to date, surgery after neoadjuvant TT has been performed safely with no difference in overall surgical mortality and morbidity $(69,82,85)$. One area of concern has been reports of delayed postoperative wound healing, though conflicting data currently exists. Some studies have shown wound healing rates after neoadjuvant therapy consistent with historical controls of upfront nephrectomy $(86,87)$, while others had concerns with delayed wound healing in up to $24 \%$ of patients $(69,83,85,88)$. To prevent wound complications, investigations of when the last dose of targeted therapy should be given before nephrectomy have been done. Thomas and colleagues suggested that withholding the drug for 2-3 half lives before and after surgery could serve to minimize these adverse effects (82). Still, no consensus guidelines on the optimal time to stop neoadjuvant therapy prior to surgery currently exist. Regardless of when it is stopped, careful surgical technique with attention to wound closure should be a priority.

Another concern of neoadjuvant-targeted therapy has been the phenomenon of tumor "rebound." While TKIs and VEGF-A decrease the vascularity of tumors, cessation of treatment can lead to rapid intratumoral angiogenesis and thus progression of disease. The mechanism of these changes has not been fully elucidated. Initial preclinical studies of such drugs suggested that an upregulation of tumorigenic and proinflammatory cytokines and growth factors, along with changes to the tumor microenvironment that increase the metastatic potential, may be responsible (89). However, few clinical studies have been done to investigate this, and much of the early evidence was from case reports $(90,91)$. One study looked at primary tumor tissues of patients treated with sunitinib or bevacizumab and compared them with those who were untreated. While the investigation found that sunitinib-treated tumors showed suppression of angiogenesis by analysis of several angiogenic markers, it also found an increased number of growing endothelial cells, suggesting that cessation of VEGF TKIs could cause quick revascularization of tumor after repression (92). Powles et al. (93) pooled data from three phase II clinical trials in which sunitinib (two studies) or pazopanib (one study) was given prior to nephrectomy in patients with mRCC. In each of the studies, a treatment break of 4-5 weeks was planned in order to minimize the risk of wound healing complications. Of the 62 patients who underwent the procedure, 23 (37\%) had radiographic evidence of progression, $77 \%$ of which had new metastatic sites, at a median follow-up of 6.3 weeks after the procedure. The study found that $70 \%$ of the patients who progressed during structured treatment break could be stabilized by reimplementation of targeted therapy. Nonetheless, the patients 
who progressed had a significantly shorter OS than those who did not (HR: 5.56, $p<0.01$ ). The authors were unable to find any factors that could be used to predict those that would progress during treatment break, although those who did progress tended to have tumors with a higher Fuhrman grade (93).

In summation, studies looking at the safety of surgical resection of kidneys in RCC after the use of various TTs seem to agree that surgery after therapy is relatively safe with tolerable morbidity and mortality outcome. Though neoadjuvant therapy may increase the risk for delays in superficial wound healing and withdrawal of therapy may result in tumor proliferation, these concerns should be weighed against the clinical benefit derived from such therapeutic strategies.

\section{NEOADJUVANT SYSTEMIC THERAPY FOR CAVAL THROMBUS DUE TO ADVANCED RCC}

Tumor thrombus extension into the IVC is a potential consequence of advanced RCC. Surgery, while often technically challenging, has historically been shown to improve long-term survival in patients without metastases $(94,95)$. Data have also suggested that the level of tumor thrombus correlates with higher perioperative complication rates $(96,97)$. Neoadjuvant therapy could potentially allow for a less complicated surgical procedure by downgrading the tumor thrombus level (98). While individual case reports have indicated some success, the overall benefit of neoadjuvant therapy for the downsizing of tumor thrombus has not yet been established. A more recent study looked at neoadjuvant sorafenib for treatment of high-risk RCC and found that four of the five patients with tumor thrombus were able to downgrade thrombus level (81). However, one of the few case series to look at neoadjuvant-targeted therapy for the downsizing of caval thrombus found that only 1 of 24 patients was able to have a significant enough downsizing to change the surgical procedure (99). This report found only $44 \%$ of patients had a decrease in tumor thrombus height, with a decrease of $1.5 \mathrm{~cm}$. Similarly, another small case series of 14 patients saw only 1 patient decrease in thrombus level with another patient increasing in thrombus level (100).

Although no conclusions can be drawn from this very limited data, physicians might consider such a therapeutic option in select cases, especially when the patient's performance status or comorbidities make surgery especially high risk. Additionally, the inherently complex nature of caval thrombus tumor removal highlights the need for a multidisciplinary team approach. Depending on the precise location of the tumor and extent of the thrombus, collaboration with vascular or thoracic surgery colleagues and cardiac anesthesiology should be considered in order to ensure the greatest likelihood of success.

\section{LYMPHADENECTOMY FOR ADVANCED RCC}

Lymph node involvement in RCC is historically associated with a poor prognosis $(101,102)$. Even in the setting of metastatic disease, nodal metastases have been associated with worse outcomes $(103,104)$. While lymph node dissection (LND) can provide diagnostic information, the low incidence of lymph node metastases in the absence of clinical suspicion, the lack of a consistent definition and template of LND, and the lack of strong evidence supporting a survival advantage for LND, have called into question the appropriate use of LND (105-107).

Nearly five decades ago, Robson and colleagues suggested the use of LND in conjunction with radical nephrectomy as a possible reason for their higher reported OS in patients with RCC (108). Since then, various studies have looked at the efficacy of LND as a treatment option and several have reported a possible benefit $(102,103,109-111)$. One retrospective study on node-positive patients, who did $(n=112)$ and did not $(n=17)$ undergo LND as part of their radical nephrectomy, reported a statistically significant survival advantage on univariate analysis $(p=0.0002)$ with a median survival benefit of about 5 months for those who underwent LND (103). Moreover, Whitson and colleagues found a positive correlation between the number of nodes removed and cancer-specific survival in node-positive patients (111). Further analysis of this same dataset by Sun and colleagues concluded that the extent of LND did not correlate with CSS for $\mathrm{pN}+$ patients (112). A more recent study reported a survival benefit associated with nodal yield (102). Each additional lymph node removed resulted in a $3-19 \%$ increase in CSS for patients with tumors larger than $10 \mathrm{~cm}, \mathrm{pT} 3 \mathrm{c}$ and pT4 tumors, or evidence of sarcomatoid features (102). Even if LND was therapeutically beneficial to $\mathrm{pN}+$, the incidence of $\mathrm{pN}+$ without clinical suspicion ranges $3.3-4.1 \%$, which would make the number of patients needed to treat for a potential benefit high $(105,113,114)$.

Conversely, several retrospective studies have shown there to be no survival benefit for LND in $\operatorname{RCC}(103,112,115,116)$. Additionally, an EORTC phase III randomized control trial found no significant difference in OS, time to disease progression, or PFS between those who received a radical nephrectomy plus complete LND versus those who received radical nephrectomy alone (105). Although the RCT did not find a therapeutic benefit in LND, the study only examined patients with surgically resectable tumors (majority were pT2) who were found to be N0M0 on preoperative imaging and reported $\mathrm{N}+$ disease in only $4 \%$ of subjects who underwent LND. While clinical node status detects a majority of pathological node-positive cases, it is well understood that regional lymphadenopathy is frequently due to inflammatory changes and not RCC metastases (117). For the improvement in identification of RCC patients at high risk for lymph node metastases, several indicators have been created (Table 3) (114, 118-121).

This discrepancy in the literature may be attributed to the variation and lack of standardization on the extent and location of dissection. Typically, the right renal lymphatics drain into paracaval, precaval, interaortocaval, and retrocaval lymph nodes, while the left renal lymphatics drain into preaortic, paraaortic, and retroaortic lymph nodes (123). Although a limited LND of the hilar nodes would be the most convenient for removal and sampling, nodal metastases outside of this region are frequently seen without the presence of hilar metastases $(106,107)$. Specific dissection templates have been described in the literature 
TABLE 3 | Selected tool used in the identification of renal cell carcinoma patients at high risk for lymph node metastases.

\begin{tabular}{lcl}
\hline Reference & $\begin{array}{c}\text { Predicted accuracy } \\
\text { (AUC) (\%) }\end{array}$ & Factors \\
\hline $\begin{array}{l}\text { Blute } \\
\text { et al. (118) }\end{array}$ & N/A & $\begin{array}{l}\text { Nuclear grade 3/4, sarcomatoid } \\
\text { component, tumor }>10 \mathrm{~cm}, \\
\text { tumor pT3/pT4, histological tumor } \\
\text { necrosis }\end{array}$ \\
\hline $\begin{array}{l}\text { Hutterer } \\
\text { et al. (119) }\end{array}$ & 78.4 & $\begin{array}{l}\text { Age, symptoms (systematic, local, } \\
\text { asymptomatic), tumor size }\end{array}$ \\
\hline $\begin{array}{l}\text { Capitanio } \\
\text { et al. (114) }\end{array}$ & 86.9 & $\begin{array}{l}\text { Clinical T3-T4, clinical node status, } \\
\text { presence of metastases, clinical } \\
\text { tumor size }\end{array}$ \\
\hline $\begin{array}{l}\text { Babaian } \\
\text { et al. (120) }\end{array}$ & & $\begin{array}{l}\text { ECOG performance score, clinical } \\
\text { node status, local symptoms, } \\
\text { lactate dehydrogenase }\end{array}$ \\
\hline $\begin{array}{l}\text { Gershman } \\
\text { et al. (121) }\end{array}$ & 89.0 & $\begin{array}{l}\text { LN short axis, radiographic } \\
\text { perinephric/sinus fat invasion }\end{array}$ \\
\hline
\end{tabular}

(106, 108, 124-126). However, there has been no consensus on the most favorable approach. Regardless, optimizing the amount of lymph nodes examined should be paramount. Terrone and colleagues found that increasing nodal yield also increased the percentage of positive nodes found and concluded that more than 12 nodes were needed to be examined for sufficient staging (127). Likewise, a more recent study by Capitanio et al. (122) calculated the number of nodes required to reach a $90 \%$ chance of finding a positive node for each risk group previously established by the Mayo clinic (118). For low-, intermediate-, and high-risk groups, it was calculated that 13,16 , and 21 nodes, respectively, were needed to reach the $90 \%$ threshold (122).

Currently, the usage of LND with nephrectomy has been decreasing (128), which might be due in part to refinements in cross-sectional imaging that have improved our ability to clinically stage patients at risk of nodal disease. With mixed results in retrospective studies of LND as a therapeutic measure, and the only RCT showing no survival benefit, more prospective studies are needed to evaluate the efficacy of LND and stratify patients by who may and may not benefit from it. Furthermore, standardization of the LND template will be needed to create consistency in both clinical practice and future trials.

\section{METASTASECTOMY FOR RCC}

As previously described, the introduction of TTs into treatment pathways has significantly improved OS in the setting of mRCC. Despite the benefits offered by systemic therapies, surgical resection of distant metastatic lesions, or metastasectomy, remains an option for carefully selected patients. Though the effect of such treatment has been highlighted in several retrospective analyses, there is a lack of level 1 evidence owing to the absence of randomized clinical trials.

Several early studies found resection was often feasible and effective in patients presenting with solitary metastasis $(129,130)$. The role of metastasectomy was later expanded to include patients with metastatic lesions in multiple organs. A retrospective analysis, performed prior to the TT era, of 278 patients with mRCC found the 5-year OS rate to be $44 \%$ for patients undergoing curative resection of metastatic tumors (131). Predictably, a higher disease burden was associated with poorer outcomes, as the 5-year OS rate was significantly lower in those with multiple sites of metastasis compared to those with a single site (29 vs. $54 \%, p<0.001)$. Of note, for patients who did not undergo any surgical resection, the 5 -year OS rate was only $11 \%$, without any systemic therapy.

Alt et al. (132) was able to demonstrate a significant survival benefit for complete metastatic resection when the number of metastatic lesions was either 2 or $\geq 3$ ( $p<0.001$ for both). Overall, patients who did not have any resection of metastases in this study had a 3-fold increased risk of death from RCC, even after controlling for the number, location, and timing of metastases, as well as the patients' ECOG status (132). Regardless of disease burden, the value of complete metastasectomy compared to incomplete resection has been established. In the previous analysis, the 5-year estimated CSS rate was significantly higher for those who had complete versus incomplete resection of metastases (49.4 vs. $23.7 \%$, respectively), though both were significantly higher than in patients who had no resection at all (8.9\%) (132). Furthermore, Naito et al. (133) evaluated 556 patients with mRCC who had either complete or incomplete resection of their metastatic sites and showed a survival benefit of more than 70 months for patients who underwent complete resection versus incomplete (109.8 vs. 31.9 months; $p<0.001)$. This is consistent with work from Daliani and colleagues (134), who reported a median survival time of 5.6 years after complete resection versus 1.4 years for incomplete resection. A meta-analysis found a median 40.8-month longer OS and cancer-specific survival benefit of 14.8 months for complete resection (135). However, the existing data used for this analysis may reflect a selection bias of healthy patients for complete metastasectomy and the utilization of incomplete resection for palliative, not curative, effects. Addressing this issue, Zaid et al. (136) recently performed a similar meta-analysis of studies to compare complete versus incomplete metastasectomy or no surgery at all. They found comparable HRs for overall mortality in patients who had a complete metastasectomy, regardless of whether the study did or did not adjust for baseline performance status ( 2.59 vs. $2.16, p=0.27$, respectively). Overall, the pooled adjusted HR of 2.37 (95\% CI, 2.03-2.87; $p<0.001$ ) suggests that complete metastasectomy is advantageous when clinically feasible.

Combination treatments with systemic and surgical modalities have been investigated in order to enhance outcomes in this population. In the cytokine therapy era, several small retrospective series showed this was a reasonable approach (137-140). Later, Karam et al. (141) retrospectively analyzed 22 patients treated with targeted therapy and metastasectomy. They included those who had at least one cycle of targeted therapy prior to complete metastasectomy. At a median follow-up of 109 weeks after surgery, all but one of the patients was alive and at a median of 43 weeks and 50\% had no tumor recurrence. Importantly, they noted only four patients had a total of six perioperative complications (four chylous ascites, one atrial fibrillation, and one ileus), which all were corrected with appropriate therapy. 
This interaction between metastasectomy and adjuvant systemic therapy must be examined further in well-designed clinical trials. One such trial, EGOG 2810 (NCT01575548) is a phase III study that is randomizing patients who have no evidence of disease following metastasectomy to receive either pazopanib or placebo using a primary outcome of DFS.

Renal cell carcinoma most often metastasizes to the lung, bone, lymph nodes, liver, pancreas, adrenal, and brain, with lungs the most common site (142). The 5-year OS rates for patients after pulmonary metastasectomy have been reported to range from 36 to $54 \%$, with solitary metastatic lesions a good prognostic indicator for survival (143). Metastases to the pancreas have also been reported to have favorable outcomes following metastasectomy, with 5 -year survival rates as high as $88 \%$ (144). In fact, a recent report found no statistically significant difference in recurrence free survival after complete metastasectomy in patients with either adrenal, liver, lung or pancreatic metastases (145). On the other hand, brain metastases have been reported in $2-17 \%$ of patients with mRCC (146-149). Outcomes are poor in these patients, with median OS of 10.7 months and 5-year survival rates of only $12 \%$ (150). Treatment for these patients is often palliative, and surgery, radiotherapy, stereotactic radiosurgery (STRS), and systemic treatments are frequently used in combination. Nieder and colleagues analyzed patients with metastatic RCC to the brain, and found median OS was greater in the subset of patients that underwent surgery with or without STRS versus those who had whole-brain radiotherapy alone (10.1 vs. 4.1 months) (151). Conversely, Ikushima et al. (152) compared metastasectomy plus radiotherapy with STRS, or conventional radiotherapy alone. Patients that underwent STRS had the highest median survival of 25.6 months, while the metastasectomy and conventional radiotherapy groups were 18.7 and 4.3 months, respectively. While this study suggests STRS should initially be considered for these patients, overall the data are quite limited and reinforce the need for a multimodal approach.

As mentioned previously, sarcomatoid differentiation accounts for $1-8 \%$ of renal tumors and has been shown to confer a poor prognosis for patients with RCC. Unfortunately, therapeutic options are limited for these patients as treatment with conventional chemotherapy, cytokine-based immunotherapy, or TTs do not provide much benefit (153-155). To identify whether metastasectomy offered a survival advantage to patients with sarcomatoid mRCC, Thomas et al. (156) identified 273 patients from an institutional database who underwent nephrectomy and were found to have sarcomatoid RCC before developing metastases. These patients then underwent metastasectomy of resectable sites. A control group of patients who did not receive metastasectomy were matched to these patients based on ECOG performance status, age, histology, pathological stage, and nodal status. For patients with synchronous metastases, median OS was 8.4 months for those who underwent metastasectomy and 8.0 months in the non-metastasectomy group $(p=0.35)$. Similarly, an observable, albeit insignificant, difference was seen in those with asynchronous metastases. The median OS in this asynchronous metastasectomy group was 36.2 months, compared to 13.7 months in the non-metastasectomy group $(p=0.29)$ (156). Even though this study did not find a significant survival benefit for metastasectomy in patients with sarcomatoid mRCC, it might still be considered in carefully selected patients, such as for palliative purposes.

\section{FUTURE DIRECTIONS}

Locally advanced and metastatic RCC continues to present a challenge for providers as optimal predictive models and treatment pathways for this patient population have yet to be defined. Refinements in functional imaging, genomic sequencing of the primary tumor/metastasis, and biomarker/nomogram development offer opportunities to close some of the knowledge gaps in this disease space (157-159). Additionally, elucidating the role of immune checkpoint inhibitors in this patient population is critical. Therefore, clinical trial participation should be considered for each patient. For example, several recently opened highpriority trials using checkpoint inhibitors are briefly described below.

PROSPER is a phase III trial designed to evaluate the effects of perioperative nivolumab on recurrence-free survival (NCT03055013). Patients with clinical stage $\geq \mathrm{T} 2 \mathrm{NxM0}$ or TanyN+ with tumors amenable to either radical or partial nephrectomy will be randomized to receive either surgery with neoadjuvant and adjuvant nivolumab or surgery alone. The use of preoperative nivolumab to help prime the immune system prior to surgical resection is an intriguing aspect to this study. Similarly, for patients with metastatic disease, the ADAPTeR study, a phase II single-arm clinical trial, has been initiated in the UK (NCT02446860). This study will assess the number of adverse events in patients in order to determine the safety of nivolumab given both before and after $\mathrm{CN}$ in patients with clear cell mRCC. In the purely adjuvant space, the IMmotion010 phase III randomized, placebo-controlled clinical trial is recruiting patients who previously underwent a radical or partial nephrectomy with lymphadenectomy for RCC with a high risk of metastatic progression or have undergone metastasectomy (NCT03024996). Atezolizumab will be given to the treatment group for 1 year, and the primary outcome is DFS.

\section{CONCLUSION}

Surgical options for patients with advanced RCC, such as CN and/or metastasectomy, continue to offer excellent opportunities for disease control and increased survival. Surgeon participation in ongoing and developing clinical trials is also of paramount importance as we explore sequenced therapies consisting of neoadjuvant therapy, extirpative surgery, and adjuvant treatment. Careful patient selection is needed to ensure a favorable risk/ benefit ratio for all patients, whether they are receiving treatment on study or off. Therefore, all patients presenting with advanced or metastatic RCC should undergo a meticulous work-up and careful staging of their disease. A thorough multidisciplinary evaluation of the patient and his or her therapeutic options is necessary to ensure that each oncology subspecialty is able to add their expertise and create an optimal and individualized treatment plan. 


\section{AUTHOR CONTRIBUTIONS}

All authors were involved in the conception, preparation, and critical review of this manuscript.

\section{REFERENCES}

1. Siegel RL, Miller KD, Jemal A. Cancer statistics, 2017. CA Cancer J Clin (2017) 67(1):7-30. doi:10.3322/caac.21387

2. Kane CJ, Mallin K, Ritchey J, Cooperberg MR, Carroll PR. Renal cell cancer stage migration: analysis of the National Cancer Data Base. Cancer (2008) 113(1):78-83. doi:10.1002/cncr.23518

3. Van Poppel H, Da Pozzo L, Albrecht W, Matveev V, Bono A, Borkowski A, et al. A prospective, randomised EORTC intergroup phase 3 study comparing the oncologic outcome of elective nephron-sparing surgery and radical nephrectomy for low-stage renal cell carcinoma. Eur Urol (2011) 59(4):543-52. doi:10.1016/j.eururo.2010.12.013

4. Li P, Wong YN, Armstrong K, Haas N, Subedi P, Davis-Cerone M, et al. Survival among patients with advanced renal cell carcinoma in the pretargeted versus targeted therapy eras. Cancer Med (2016) 5(2):169-81. doi:10.1002/ cam4.574

5. Motzer RJ, Bander NH, Nanus DM. Renal-cell carcinoma. N Engl J Med (1996) 335(12):865-75. doi:10.1056/NEJM199609193351207

6. Janzen NK, Kim HL, Figlin RA, Belldegrun AS. Surveillance after radical or partial nephrectomy for localized renal cell carcinoma and management of recurrent disease. Urol Clin North Am (2003) 30(4):843-52. doi:10.1016/ S0094-0143(03)00056-9

7. Lam JS, Leppert JT, Belldegrun AS, Figlin RA. Novel approaches in the therapy of metastatic renal cell carcinoma. World J Urol (2005) 23(3):202-12. doi:10.1007/s00345-004-0466-0

8. Atkins MB, Sparano J, Fisher RI, Weiss GR, Margolin KA, Fink KI, et al. Randomized phase II trial of high-dose interleukin-2 either alone or in combination with interferon alfa-2b in advanced renal cell carcinoma. J Clin Oncol (1993) 11(4):661-70. doi:10.1200/JCO.1993.11.4.661

9. Walther MM, Alexander RB, Weiss GH, Venzon D, Berman A, Pass $\mathrm{HI}$, et al. Cytoreductive surgery prior to interleukin-2-based therapy in patients with metastatic renal cell carcinoma. Urol (1993) 42(3):250-7. doi:10.1016/0090-4295(93)90612-E

10. Flanigan RC, Salmon SE, Blumenstein BA, Bearman SI, Roy V, McGrath PC, et al. Nephrectomy followed by interferon alfa-2b compared with interferon alfa-2b alone for metastatic renal-cell cancer. N Engl J Med (2001) 345(23): 1655-9. doi:10.1056/NEJMoa003013

11. Mickisch GH, Garin A, van Poppel H, de Prijck L, Sylvester R; European Organisation for Research and Treatment of Cancer (EORTC) Genitourinary Group. Radical nephrectomy plus interferon-alfa-based immunotherapy compared with interferon alfa alone in metastatic renal-cell carcinoma: a randomised trial. Lancet (2001) 358(9286):966-70. doi:10.1016/S01406736(01)06103-7

12. Lara PN Jr, Tangen CM, Conlon SJ, Flanigan RC, Crawford ED; Southwest Oncology Group Trial S. Predictors of survival of advanced renal cell carcinoma: long-term results from Southwest Oncology Group Trial S8949. J Urol (2009) 181(2):512-6; discussion 516-7. doi:10.1016/j.juro.2008.10.021

13. Flanigan RC, Mickisch G, Sylvester R, Tangen C, Van Poppel H, Crawford ED. Cytoreductive nephrectomy in patients with metastatic renal cancer: a combined analysis. J Urol (2004) 171(3):1071-6. doi:10.1097/01.ju.0000110610. 61545.ae

14. Zini L, Capitanio U, Perrotte P, Jeldres C, Shariat SF, Arjane P, et al. Populationbased assessment of survival after cytoreductive nephrectomy versus no surgery in patients with metastatic renal cell carcinoma. Urology (2009) 73(2):342-6. doi:10.1016/j.urology.2008.09.022

15. Allard CB, Gelpi-Hammerschmidt F, Harshman LC, Choueiri TK, Faiena I, Modi P, et al. Contemporary trends in high-dose interleukin-2 use for metastatic renal cell carcinoma in the United States. Urol Oncol (2015) 33(11): 496. e11-6. doi:10.1016/j.urolonc.2015.06.014

16. Modi PK, Farber NJ, Singer EA. Precision oncology: identifying predictive biomarkers for the treatment of metastatic renal cell carcinoma. Transl Cancer Res (2016) 5(Suppl 1):S76-80. doi:10.21037/tcr.2016.06.05

\section{FUNDING}

This work is supported by a grant from the National Cancer Institute (P30CA072720).

17. Conti SL, Thomas IC, Hagedorn JC, Chung BI, Chertow GM, Wagner TH, et al. Utilization of cytoreductive nephrectomy and patient survival in the targeted therapy era. Int J Cancer (2014) 134(9):2245-52. doi:10.1002/ijc.28553

18. Psutka SP, Kim SP, Gross CP, Van Houten H, Thompson RH, Abouassaly R, et al. The impact of targeted therapy on management of metastatic renal cell carcinoma: trends in systemic therapy and cytoreductive nephrectomy utilization. Urology (2015) 85(2):442-50. doi:10.1016/j.urology. 2014.10.040

19. Tsao CK, Small AC, Kates M, Moshier EL, Wisnivesky JP, Gartrell BA, et al. Cytoreductive nephrectomy for metastatic renal cell carcinoma in the era of targeted therapy in the United States: a SEER analysis. World J Urol (2013) 31:1535-9. doi:10.1007/s00345-012-1001-3

20. Fyfe G, Fisher RI, Rosenberg SA, Sznol M, Parkinson DR, Louie AC. Results of treatment of 255 patients with metastatic renal cell carcinoma who received high-dose recombinant interleukin-2 therapy. J Clin Oncol (1995) 13(3):688-96. doi:10.1200/JCO.1995.13.3.688

21. Escudier B, Eisen T, Stadler WM, Szczylik C, Oudard S, Siebels M, et al. Sorafenib in advanced clear-cell renal-cell carcinoma. N Engl J Med (2007) 356(2):125-34. doi:10.1056/NEJMoa060655

22. Motzer RJ, Hutson TE, Tomczak P, Michaelson MD, Bukowski RM, Rixe O, et al. Sunitinib versus interferon alfa in metastatic renal-cell carcinoma. $N$ Engl J Med (2007) 356(2):115-24. doi:10.1056/NEJMoa065044

23. Hudes G, Carducci M, Tomczak P, Dutcher J, Figlin R, Kapoor A, et al. Temsirolimus, interferon alfa, or both for advanced renal-cell carcinoma. $N$ Engl J Med (2007) 356(22):2271-81. doi:10.1056/NEJMoa066838

24. Motzer RJ, Escudier B, Oudard S, Hutson TE, Porta C, Bracarda S, et al. Efficacy of everolimus in advanced renal cell carcinoma: a double-blind, randomised, placebo-controlled phase III trial. Lancet (2008) 372(9637):449-56. doi:10.1016/S0140-6736(08)61039-9

25. Escudier B, Bellmunt J, Negrier S, Bajetta E, Melichar B, Bracarda S, et al. Phase III trial of bevacizumab plus interferon alfa-2a in patients with metastatic renal cell carcinoma (AVOREN): final analysis of overall survival. J Clin Oncol (2010) 28(13):2144-50. doi:10.1200/JCO.2009.26.7849

26. Rini BI, Halabi S, Rosenberg JE, Stadler WM, Vaena DA, Archer L, et al. Phase III trial of bevacizumab plus interferon alfa versus interferon alfa monotherapy in patients with metastatic renal cell carcinoma: final results of CALGB 90206. J Clin Oncol (2010) 28(13):2137-43. doi:10.1200/JCO.2009.26.5561

27. Sternberg CN, Davis ID, Mardiak J, Szczylik C, Lee E, Wagstaff J, et al. Pazopanib in locally advanced or metastatic renal cell carcinoma: results of a randomized phase III trial. J Clin Oncol (2010) 28(6):1061-8. doi:10.1200/ JCO.2009.23.9764

28. Rini BI, Escudier B, Tomczak P, Kaprin A, Szczylik C, Hutson TE, et al. Comparative effectiveness of axitinib versus sorafenib in advanced renal cell carcinoma (AXIS): a randomised phase 3 trial. Lancet (2011) 378(9807):1931-9. doi:10.1016/s0140-6736(11)61613-9

29. Motzer RJ, Escudier B, McDermott DF, George S, Hammers HJ, Srinivas S, et al. Nivolumab versus everolimus in advanced renal-cell carcinoma. $N$ Engl J Med (2015) 373(19):1803-13. doi:10.1056/NEJMoa1510665

30. Choueiri TK, Escudier B, Powles T, Mainwaring PN, Rini BI, Donskov F, et al. Cabozantinib versus everolimus in advanced renal-cell carcinoma. N Engl J Med (2015) 373(19):1814-23. doi:10.1056/NEJMoa1510016

31. Motzer RJ, Hutson TE, Glen H, Michaelson MD, Molina A, Eisen T, et al. Lenvatinib, everolimus, and the combination in patients with metastatic renal cell carcinoma: a randomised, phase 2, open-label, multicentre trial. Lancet Oncol (2015) 16(15):1473-82. doi:10.1016/S1470-2045(15)00290-9

32. Choueiri TK, Xie W, Kollmannsberger C, North S, Knox JJ, Lampard JG, et al. The impact of cytoreductive nephrectomy on survival of patients with metastatic renal cell carcinoma receiving vascular endothelial growth factor targeted therapy. J Urol (2011) 185(1):60-6. doi:10.1016/j.juro.2010.09.012

33. Heng DY, Wells JC, Rini BI, Beuselinck B, Lee JL, Knox JJ, et al. Cytoreductive nephrectomy in patients with synchronous metastases from renal cell carcinoma: results from the International Metastatic Renal Cell Carcinoma 
Database Consortium. Eur Urol (2014) 66(4):704-10. doi:10.1016/j.eururo. 2014.05.034

34. Hanna N, Sun M, Meyer CP, Nguyen PL, Pal SK, Chang SL, et al. Survival analyses of patients with metastatic renal cancer treated with targeted therapy with or without cytoreductive nephrectomy: a national cancer data base study. J Clin Oncol (2016) 34(27):3267-75. doi:10.1200/JCO.2016.66.7931

35. Petrelli F, Coinu A, Vavassori I, Cabiddu M, Borgonovo K, Ghilardi M, et al. Cytoreductive nephrectomy in metastatic renal cell carcinoma treated with targeted therapies: a systematic review with a meta-analysis. Clin Genitourin Cancer (2016) 14(6):465-72. doi:10.1016/j.clgc.2016.04.001

36. Mathieu R, Pignot G, Ingles A, Crepel M, Bigot P, Bernhard JC, et al. Nephrectomy improves overall survival in patients with metastatic renal cell carcinoma in cases of favorable MSKCC or ECOG prognostic features. Urol Oncol (2015) 33(8): 339.e9-15. doi:10.1016/j.urolonc.2015.05.014

37. Trinh QD, Bianchi M, Hansen J, Tian Z, Abdollah F, Shariat SF, et al. In-hospital mortality and failure to rescue after cytoreductive nephrectomy. Eur Urol (2013) 63(6):1107-14. doi:10.1016/j.eururo.2012.08.069

38. Gershman B, Moreira DM, Boorjian SA, Lohse CM, Cheville JC, Costello BA, et al. Comprehensive characterization of the perioperative morbidity of cytoreductive nephrectomy. Eur Urol (2016) 69(1):84-91. doi:10.1016/j.eururo. 2015.05.022

39. Cloutier V, Capitanio U, Zini L, Perrotte P, Jeldres C, Shariat SF, et al. Thirtyday mortality after nephrectomy: clinical implications for informed consent. Eur Urol (2009) 56(6):998-1003. doi:10.1016/j.eururo.2008.11.023

40. Sun M, Abdollah F, Schmitges J, Bianchi M, Tian Z, Shariat SF, et al. Cytoreductive nephrectomy in the elderly: a population-based cohort from the USA. BJU Int (2012) 109(12):1807-12. doi:10.1111/j.1464-410X.2011.10569.x

41. Fallick ML, McDermott DF, LaRock D, Long JP, Atkins MB. Nephrectomy before interleukin-2 therapy for patients with metastatic renal cell carcinoma. J Urol (1997) 158(5):1691-5. doi:10.1016/S0022-5347(01)64097-7

42. Walther MM, Yang JC, Pass HI, Linehan WM, Rosenberg SA. Cytoreductive surgery before high dose interleukin-2 based therapy in patients with metastatic renal cell carcinoma. J Urol (1997) 158(5):1675-8. doi:10.1016/ S0022-5347(01)64091-6

43. Bennett RT, Lerner SE, Taub HC, Dutcher JP, Fleischmann J. Cytoreductive surgery for stage IV renal cell carcinoma. J Urol (1995) 154(1):32-4. doi:10.1016/S0022-5347(01)67217-3

44. Kassouf W, Sanchez-Ortiz R, Tamboli P, Tannir N, Jonasch E, Merchant MM, et al. Cytoreductive nephrectomy for metastatic renal cell carcinoma with nonclear cell histology. J Urol (2007) 178(5):1896-900. doi:10.1016/j.juro. 2007.07.037

45. Culp SH, Tannir NM, Abel EJ, Margulis V, Tamboli P, Matin SF, et al. Can we better select patients with metastatic renal cell carcinoma for cytoreductive nephrectomy? Cancer (2010) 116(14):3378-88. doi:10.1002/cncr.25046

46. Margulis V, Shariat SF, Rapoport Y, Rink M, Sjoberg DD, Tannir NM, et al. Development of accurate models for individualized prediction of survival after cytoreductive nephrectomy for metastatic renal cell carcinoma. Eur Urol (2013) 63(5):947-52. doi:10.1016/j.eururo.2012.11.040

47. Abel EJ, Culp SH, Tannir NM, Tamboli P, Matin SF, Wood CG. Early primary tumor size reduction is an independent predictor of improved overall survival in metastatic renal cell carcinoma patients treated with sunitinib. Eur Urol (2011) 60(6):1273-9. doi:10.1016/j.eururo.2011.07.008

48. Wood CG. Multimodal approaches in the management of locally advanced and metastatic renal cell carcinoma: combining surgery and systemic therapies to improve patient outcome. Clin Cancer Res (2007) 13(2 Pt 2):697s-702s. doi:10.1158/1078-0432.CCR-06-2109

49. Kroeger N, Xie W, Lee JL, Bjarnason GA, Knox JJ, Mackenzie MJ, et al. Metastatic non-clear cell renal cell carcinoma treated with targeted therapy agents: characterization of survival outcome and application of the International mRCC Database Consortium criteria. Cancer (2013) 119(16):2999-3006. doi:10.1002/cncr.28151

50. Shuch B, Said J, La Rochelle JC, Zhou Y, Li G, Klatte T, et al. Cytoreductive nephrectomy for kidney cancer with sarcomatoid histology-is up-front resection indicated and, if not, is it avoidable? J Urol (2009) 182(5):2164-71. doi:10.1016/j.juro.2009.07.049

51. Abel EJ, Carrasco A, Culp SH, Matin SF, Tamboli P, Tannir NM, et al. Limitations of preoperative biopsy in patients with metastatic renal cell carcinoma: comparison to surgical pathology in 405 cases. BJU Int (2012) 110(11):1742-6. doi:10.1111/j.1464-410X.2012.11124.x
52. Upton MP, Parker RA, Youmans A, McDermott DF, Atkins MB. Histologic predictors of renal cell carcinoma response to interleukin-2-based therapy. J Immunother (2005) 28(5):488-95. doi:10.1097/01.cji.0000170357.14962.9b

53. Choueiri TK, Plantade A, Elson P, Negrier S, Ravaud A, Oudard S, et al. Efficacy of sunitinib and sorafenib in metastatic papillary and chromophobe renal cell carcinoma. J Clin Oncol (2008) 26(1):127-31. doi:10.1200/JCO.2007.13.3223

54. Iacovelli R, Lanoy E, Albiges L, Escudier B. Tumour burden is an independent prognostic factor in metastatic renal cell carcinoma. BJU Int (2012) 110(11):1747-53. doi:10.1111/j.1464-410X.2012.11518.x

55. Pierorazio PM, McKiernan JM, McCann TR, Mohile S, Petrylak D, Benson MC. Outcome after cytoreductive nephrectomy for metastatic renal cell carcinoma is predicted by fractional percentage of tumour volume removed. BJU Int (2007) 100(4):755-9. doi:10.1111/j.1464-410X.2007.07108.x

56. Barbastefano J, Garcia JA, Elson P, Wood LS, Lane BR, Dreicer R, et al. Association of percentage of tumour burden removed with debulking nephrectomy and progression-free survival in patients with metastatic renal cell carcinoma treated with vascular endothelial growth factor-targeted therapy. BJU Int (2010) 106(9):1266-9. doi:10.1111/j.1464-410X.2010.09323.x

57. Van Poppel H, Da Pozzo L, Albrecht W, Matveev V, Bono A, Borkowski A, et al. A prospective randomized EORTC intergroup phase 3 study comparing the complications of elective nephron-sparing surgery and radical nephrectomy for low-stage renal cell carcinoma. Eur Urol (2007) 51(6):1606-15. doi:10.1016/j.eururo.2006.11.013

58. Huang WC, Levey AS, Serio AM, Snyder M, Vickers AJ, Raj GV, et al. Chronic kidney disease after nephrectomy in patients with renal cortical tumours: a retrospective cohort study. Lancet Oncol (2006) 7(9):735-40. doi:10.1016/ S1470-2045(06)70803-8

59. Patard JJ, Shvarts O, Lam JS, Pantuck AJ, Kim HL, Ficarra V, et al. Safety and efficacy of partial nephrectomy for all T1 tumors based on an international multicenter experience. J Urol (2004) 171(6 Pt 1):2181-5, quiz 2435. doi:10.1097/01.ju.0000124846.37299.5e

60. Becker F, Siemer S, Hack M, Humke U, Ziegler M, Stockle M. Excellent longterm cancer control with elective nephron-sparing surgery for selected renal cell carcinomas measuring more than $4 \mathrm{~cm}$. Eur Urol (2006) 49(6):1058-63; discussion 1063-4. doi:10.1016/j.eururo.2006.03.003

61. Margulis V, Tamboli P, Jacobsohn KM, Swanson DA, Wood CG. Oncological efficacy and safety of nephron-sparing surgery for selected patients with locally advanced renal cell carcinoma. BJU Int (2007) 100(6):1235-9. doi:10.1111/j.1464-410X.2007.07225.x

62. Krishnamurthi V, Novick AC, Bukowski R. Nephron sparing surgery in patients with metastatic renal cell carcinoma. J Urol (1996) 156(1):36-9. doi:10.1097/00005392-199607000-00008

63. Krambeck AE, Leibovich BC, Lohse CM, Kwon ED, Zincke H, Blute ML. The role of nephron sparing surgery for metastatic (pM1) renal cell carcinoma. J Urol (2006) 176(5):1990-5; discussion 1995. doi:10.1016/j.juro.2006.07.015

64. Hutterer GC, Patard JJ, Colombel M, Belldegrun AS, Pfister C, Guille F, et al. Cytoreductive nephron-sparing surgery does not appear to undermine disease-specific survival in patients with metastatic renal cell carcinoma. Cancer (2007) 110(11):2428-33. doi:10.1002/cncr.23054

65. Capitanio U, Zini L, Perrotte P, Shariat SF, Jeldres C, Arjane P, et al. Cytoreductive partial nephrectomy does not undermine cancer control in metastatic renal cell carcinoma: a population-based study. Urology (2008) 72(5):1090-5. doi:10.1016/j.urology.2008.06.059

66. Hellenthal NJ, Mansour AM, Hayn MH, Schwaab T. Is there a role for partial nephrectomy in patients with metastatic renal cell carcinoma? Urol Oncol (2013) 31(1):36-41. doi:10.1016/j.urolonc.2010.08.026

67. Wagner JR, Walther MM, Linehan WM, White DE, Rosenberg SA, Yang JC. Interleukin-2 based immunotherapy for metastatic renal cell carcinoma with the kidney in place. J Urol (1999) 162(1):43-5. doi:10.1097/00005392199907000-00011

68. Wood CG, Margulis V. Neoadjuvant (presurgical) therapy for renal cell carcinoma: a new treatment paradigm for locally advanced and metastatic disease. Cancer (2009) 115(10 Suppl):2355-60. doi:10.1002/cncr.24240

69. Powles T, Sarwar N, Stockdale A, Sarker SJ, Boleti E, Protheroe A, et al. Safety and efficacy of pazopanib therapy prior to planned nephrectomy in metastatic clear cell renal cancer. JAMA Oncol (2016) 2(10):1303-9. doi:10.1001/ jamaoncol.2016.1197

70. Thomas AA, Rini BI, Lane BR, Garcia J, Dreicer R, Klein EA, et al. Response of the primary tumor to neoadjuvant sunitinib in patients with advanced renal 
cell carcinoma. J Urol (2009) 181(2):518-23; discussion 523. doi:10.1016/j. juro.2008.10.001

71. Rini BI, Garcia J, Elson P, Wood L, Shah S, Stephenson A, et al. The effect of sunitinib on primary renal cell carcinoma and facilitation of subsequent surgery. J Urol (2012) 187(5):1548-54. doi:10.1016/j.juro.2011.12.075

72. van der Veldt AA, Meijerink MR, van den Eertwegh AJ, Bex A, de Gast G, Haanen JB, et al. Sunitinib for treatment of advanced renal cell cancer: primary tumor response. Clin Cancer Res (2008) 14(8):2431-6. doi:10.1158/1078-0432. CCR-07-4089

73. Cowey CL, Amin C, Pruthi RS, Wallen EM, Nielsen ME, Grigson G, et al. Neoadjuvant clinical trial with sorafenib for patients with stage II or higher renal cell carcinoma. J Clin Oncol (2010) 28(9):1502-7. doi:10.1200/ JCO.2009.24.7759

74. Hellenthal NJ, Underwood W, Penetrante R, Litwin A, Zhang S, Wilding GE, et al. Prospective clinical trial of preoperative sunitinib in patients with renal cell carcinoma. J Urol (2010) 184(3):859-64. doi:10.1016/j.juro.2010.05.041

75. Silberstein JL, Millard F, Mehrazin R, Kopp R, Bazzi W, DiBlasio CJ, et al. Feasibility and efficacy of neoadjuvant sunitinib before nephron-sparing surgery. BJU Int (2010) 106(9):1270-6. doi:10.1111/j.1464-410X. 2010.09357.x

76. Bex A, Blank C, Meinhardt W, van Tinteren H, Horenblas S, Haanen J. A phase II study of presurgical sunitinib in patients with metastatic clear-cell renal carcinoma and the primary tumor in situ. Urology (2011) 78(4):832-7. doi:10.1016/j.urology.2011.05.034

77. Powles T, Blank C, Chowdhury S, Horenblas S, Peters J, Shamash J, et al. The outcome of patients treated with sunitinib prior to planned nephrectomy in metastatic clear cell renal cancer. Eur Urol (2011) 60(3):448-54. doi:10.1016/j. eururo.2011.05.028

78. Karam JA, Devine CE, Urbauer DL, Lozano M, Maity T, Ahrar K, et al. Phase 2 trial of neoadjuvant axitinib in patients with locally advanced nonmetastatic clear cell renal cell carcinoma. Eur Urol (2014) 66(5):874-80. doi:10.1016/j. eururo.2014.01.035

79. Lane BR, Derweesh IH, Kim HL, O’Malley R, Klink J, Ercole CE, et al. Presurgical sunitinib reduces tumor size and may facilitate partial nephrectomy in patients with renal cell carcinoma. Urol Oncol (2015) 33(3): 112. e15-21. doi:10.1016/j.urolonc.2014.11.009

80. Rini BI, Plimack ER, Takagi T, Elson P, Wood LS, Dreicer R, et al. A phase II study of pazopanib in patients with localized renal cell carcinoma to optimize preservation of renal parenchyma. J Urol (2015) 194(2):297-303. doi:10.1016/j.juro.2015.03.096

81. Zhang Y, Li Y, Deng J, Ji Z, Yu H, Li H. Sorafenib neoadjuvant therapy in the treatment of high risk renal cell carcinoma. PLoS One (2015) 10(2):e0115896. doi:10.1371/journal.pone.0115896

82. Thomas AA, Rini BI, Stephenson AJ, Garcia JA, Fergany A, Krishnamurthi V, et al. Surgical resection of renal cell carcinoma after targeted therapy. J Urol (2009) 182(3):881-6. doi:10.1016/j.juro.2009.05.014

83. Powles T, Kayani I, Blank C, Chowdhury S, Horenblas S, Peters J, et al. The safety and efficacy of sunitinib before planned nephrectomy in metastatic clear cell renal cancer. Ann Oncol (2011) 22(5):1041-7. doi:10.1093/annonc/ mdq564

84. Karam JA, Devine CE, Fellman BM, Urbauer DL, Abel EJ, Allaf ME, et al. Variability of inter-observer agreement on feasibility of partial nephrectomy before and after neoadjuvant axitinib for locally advanced renal cell carcinoma (RCC): independent analysis from a phase II trial. BJU Int (2016) 117(4):629-35. doi:10.1111/bju.13188

85. Chapin BF, Delacroix SE Jr, Culp SH, Nogueras Gonzalez GM, Tannir NM, Jonasch E, et al. Safety of presurgical targeted therapy in the setting of metastatic renal cell carcinoma. Eur Urol (2011) 60(5):964-71. doi:10.1016/j.eururo. 2011.05.032

86. Margulis V, Matin SF, Tannir N, Tamboli P, Swanson DA, Jonasch E, et al. Surgical morbidity associated with administration of targeted molecular therapies before cytoreductive nephrectomy or resection of locally recurrent renal cell carcinoma. J Urol (2008) 180(1):94-8. doi:10.1016/j.juro.2008.03.047

87. Harshman LC, Yu RJ, Allen GI, Srinivas S, Gill HS, Chung BI. Surgical outcomes and complications associated with presurgical tyrosine kinase inhibition for advanced renal cell carcinoma (RCC). Urol Oncol (2013) 31(3):379-85. doi:10.1016/j.urolonc.2011.01.005

88. Jonasch E, Wood CG, Matin SF, Tu SM, Pagliaro LC, Corn PG, et al. Phase II presurgical feasibility study of bevacizumab in untreated patients with metastatic renal cell carcinoma. JClin Oncol (2009) 27(25):4076-81. doi:10.1200/JCO.2008.21.3660

89. Ebos JM, Lee CR, Cruz-Munoz W, Bjarnason GA, Christensen JG, Kerbel RS. Accelerated metastasis after short-term treatment with a potent inhibitor of tumor angiogenesis. Cancer Cell (2009) 15(3):232-9. doi:10.1016/j.ccr. 2009.01.021

90. Desar IM, Mulder SF, Stillebroer AB, van Spronsen DJ, van der Graaf WT, Mulders PF, et al. The reverse side of the victory: flare up of symptoms after discontinuation of sunitinib or sorafenib in renal cell cancer patients. A report of three cases. Acta Oncol (2009) 48(6):927-31. doi:10.1080/02841860902974167

91. Wolter P, Beuselinck B, Pans S, Schoffski P. Flare-up: an often unreported phenomenon nevertheless familiar to oncologists prescribing tyrosine kinase inhibitors. Acta Oncol (2009) 48(4):621-4. doi:10.1080/02841860802609574

92. Griffioen AW, Mans LA, de Graaf AM, Nowak-Sliwinska P, de Hoog CL, de Jong TA, et al. Rapid angiogenesis onset after discontinuation of sunitinib treatment of renal cell carcinoma patients. Clin Cancer Res (2012) 18(14):3961-71. doi:10.1158/1078-0432.CCR-12-0002

93. Powles T, Kayani I, Sharpe K, Lim L, Peters J, Stewart GD, et al. A prospective evaluation of VEGF-targeted treatment cessation in metastatic clear cell renal cancer. Ann Oncol (2013) 24(8):2098-103. doi:10.1093/annonc/mdt130

94. Reese AC, Whitson JM, Meng MV. Natural history of untreated renal cell carcinoma with venous tumor thrombus. Urol Oncol (2013) 31(7):1305-9. doi:10.1016/j.urolonc.2011.12.006

95. Haddad AQ, Wood CG, Abel EJ, Krabbe LM, Darwish OM, Thompson RH, et al. Oncologic outcomes following surgical resection of renal cell carcinoma with inferior vena caval thrombus extending above the hepatic veins: a contemporary multicenter cohort. J Urol (2014) 192(4):1050-6. doi:10.1016/j. juro.2014.03.111

96. Abel EJ, Thompson RH, Margulis V, Heckman JE, Merril MM, Darwish OM, et al. Perioperative outcomes following surgical resection of renal cell carcinoma with inferior vena cava thrombus extending above the hepatic veins: a contemporary multicenter experience. Eur Urol (2014) 66(3):584-92. doi:10.1016/j.eururo.2013.10.029

97. Haddad AQ, Leibovich BC, Abel EJ, Luo JH, Krabbe LM, Thompson RH, et al. Preoperative multivariable prognostic models for prediction of survival and major complications following surgical resection of renal cell carcinoma with suprahepatic caval tumor thrombus. Urol Oncol (2015) 33(9): 388.e1-9. doi:10.1016/j.urolonc.2015.04.010

98. Shuch B, Riggs SB, LaRochelle JC, Kabbinavar FF, Avakian R, Pantuck AJ, et al. Neoadjuvant targeted therapy and advanced kidney cancer: observations and implications for a new treatment paradigm. BJU Int (2008) 102(6):692-6. doi:10.1111/j.1464-410X.2008.07660.x

99. Cost NG, Delacroix SE Jr, Sleeper JP, Smith PJ, Youssef RF, Chapin BF, et al. The impact of targeted molecular therapies on the level of renal cell carcinoma vena caval tumor thrombus. Eur Urol (2011) 59(6):912-8. doi:10.1016/j. eururo.2011.02.032

100. Bigot P, Fardoun T, Bernhard JC, Xylinas E, Berger J, Roupret M, et al. Neoadjuvant targeted molecular therapies in patients undergoing nephrectomy and inferior vena cava thrombectomy: is it useful? World J Urol (2014) 32(1):109-14. doi:10.1007/s00345-013-1088-1

101. Trinh QD, Schmitges J, Bianchi M, Sun M, Shariat SF, Sammon J, et al. Nodepositive renal cell carcinoma in the absence of distant metastases: predictors of cancer-specific mortality in a population-based cohort. BJU Int (2012) 110(2 Pt 2):E21-7. doi:10.1111/j.1464-410X.2011.10701.x

102. Capitanio U, Suardi N, Matloob R, Roscigno M, Abdollah F, Di Trapani E, et al. Extent of lymph node dissection at nephrectomy affects cancer-specific survival and metastatic progression in specific sub-categories of patients with renal cell carcinoma (RCC). BJU Int (2014) 114(2):210-5. doi:10.1111/ bju. 12508

103. Pantuck AJ, Zisman A, Dorey F, Chao DH, Han KR, Said J, et al. Renal cell carcinoma with retroperitoneal lymph nodes: role of lymph node dissection. J Urol (2003) 169(6):2076-83. doi:10.1097/01.ju.0000066130.27119.1c

104. Kroeger N, Pantuck AJ, Wells JC, Lawrence N, Broom R, Kim JJ, et al. Characterizing the impact of lymph node metastases on the survival outcome for metastatic renal cell carcinoma patients treated with targeted therapies. Eur Urol (2015) 68(3):506-15. doi:10.1016/j.eururo.2014.11.054

105. Blom JH, van Poppel H, Marechal JM, Jacqmin D, Schroder FH, de Prijck L, et al. Radical nephrectomy with and without lymph-node dissection: final results of European Organization for Research and Treatment of Cancer 
(EORTC) randomized phase 3 trial 30881. Eur Urol (2009) 55(1):28-34. doi:10.1016/j.eururo.2008.09.052

106. Crispen PL, Breau RH, Allmer C, Lohse CM, Cheville JC, Leibovich BC, et al. Lymph node dissection at the time of radical nephrectomy for highrisk clear cell renal cell carcinoma: indications and recommendations for surgical templates. Eur Urol (2011) 59(1):18-23. doi:10.1016/j.eururo.2010. 08.042

107. Hadley DA, Stephenson RA, Samlowski WE, Dechet CB. Patterns of enlarged lymph nodes in patients with metastatic renal cell carcinoma. Urol Oncol (2011) 29(6):751-5. doi:10.1016/j.urolonc.2009.10.013

108. Robson CJ, Churchill BM, Anderson W. The results of radical nephrectomy for renal cell carcinoma. J Urol (1969) 101(3):297-301.

109. Delacroix SE Jr, Chapin BF, Chen JJ, Nogueras-Gonzalez GM, Tamboli P, Matin SF, et al. Can a durable disease-free survival be achieved with surgical resection in patients with pathological node positive renal cell carcinoma? J Urol (2011) 186(4):1236-41. doi:10.1016/j.juro.2011.05.051

110. Kwon T, Song C, Hong JH, Kim CS, Ahn H. Reassessment of renal cell carcinoma lymph node staging: analysis of patterns of progression. Urology (2011) 77(2):373-8. doi:10.1016/j.urology.2010.06.015

111. Whitson JM, Harris CR, Reese AC, Meng MV. Lymphadenectomy improves survival of patients with renal cell carcinoma and nodal metastases. J Urol (2011) 185(5):1615-20. doi:10.1016/j.juro.2010.12.053

112. Sun M, Trinh QD, Bianchi M, Hansen J, Abdollah F, Tian Z, et al. Extent of lymphadenectomy does not improve the survival of patients with renal cell carcinoma and nodal metastases: biases associated with the handling of missing data. BJU Int (2014) 113(1):36-42. doi:10.1111/j.1464-410X.2012. 11693.x

113. Canfield SE, Kamat AM, Sanchez-Ortiz RF, Detry M, Swanson DA, Wood CG. Renal cell carcinoma with nodal metastases in the absence of distant metastatic disease (clinical stage TxN1-2M0): the impact of aggressive surgical resection on patient outcome. J Urol (2006) 175(3 Pt 1):864-9. doi:10.1016/ S0022-5347(05)00334-4

114. Capitanio U, Abdollah F, Matloob R, Suardi N, Castiglione F, Di Trapani E, et al. When to perform lymph node dissection in patients with renal cell carcinoma: a novel approach to the preoperative assessment of risk of lymph node invasion at surgery and of lymph node progression during follow-up. BJU Int (2013) 112(2):E59-66. doi:10.1111/bju.12125

115. Joslyn SA, Sirintrapun SJ, Konety BR. Impact of lymphadenectomy and nodal burden in renal cell carcinoma: retrospective analysis of the National Surveillance, Epidemiology, and End Results database. Urology (2005) 65(4):675-80. doi:10.1016/j.urology.2004.10.068

116. Feuerstein MA, Kent M, Bazzi WM, Bernstein M, Russo P. Analysis of lymph node dissection in patients with $>/=7-\mathrm{cm}$ renal tumors. World J Urol (2014) 32(6):1531-6. doi:10.1007/s00345-013-1233-x

117. Studer UE, Scherz S, Scheidegger J, Kraft R, Sonntag R, Ackermann D, et al. Enlargement of regional lymph nodes in renal cell carcinoma is often not due to metastases. J Urol (1990) 144(2 Pt 1):243-5.

118. Blute ML, Leibovich BC, Cheville JC, Lohse CM, Zincke H. A protocol for performing extended lymph node dissection using primary tumor pathological features for patients treated with radical nephrectomy for clear cell renal cell carcinoma. J Urol (2004) 172(2):465-9. doi:10.1097/ 01.ju.0000129815.91927.85

119. Hutterer GC, Patard JJ, Perrotte P, Ionescu C, de La Taille A, Salomon L, et al. Patients with renal cell carcinoma nodal metastases can be accurately identified: external validation of a new nomogram. Int J Cancer (2007) 121(11):2556-61. doi:10.1002/ijc.23010

120. Babaian KN, Kim DY, Kenney PA, Wood CG Jr, Wong J, Sanchez C, et al. Preoperative predictors of pathological lymph node metastasis in patients with renal cell carcinoma undergoing retroperitoneal lymph node dissection. J Urol (2015) 193(4):1101-7. doi:10.1016/j.juro.2014.10.096

121. Gershman B, Takahashi N, Moreira DM, Thompson RH, Boorjian SA, Lohse CM, et al. Radiographic size of retroperitoneal lymph nodes predicts pathological nodal involvement for patients with renal cell carcinoma: development of a risk prediction model. BJU Int (2016) 118(5):742-9. doi:10.1111/ bju. 13424

122. Capitanio U, Suardi N, Matloob R, Abdollah F, Castiglione F, Briganti A, et al. Staging lymphadenectomy in renal cell carcinoma must be extended: a sensitivity curve analysis. BJU Int (2013) 111(3):412-8. doi:10.1111/j. 1464-410X.2012.11313.x
123. Parker AE. Studies on the main posterior lymph channels of the abdomen and their connections with the lymphatics of the genito-urinary system. Am $J$ Anat (1935) 56(3):409-43. doi:10.1002/aja.1000560305

124. Wood DP Jr. Role of lymphadenectomy in renal cell carcinoma. Urol Clin North Am (1991) 18(3):421-6.

125. Palapattu GS, Kim HL, Belldegrun AS. Lymph node dissection in patients with kidney cancer: when is it indicated? Rev Urol (2003) 5(3):196-9.

126. Delacroix SE Jr, Wood CG. The role of lymphadenectomy in renal cell carcinoma. Curr Opin Urol (2009) 19(5):465-72. doi:10.1097/MOU. 0b013e32832f0c48

127. Terrone C, Guercio S, De Luca S, Poggio M, Castelli E, Scoffone C, et al. The number of lymph nodes examined and staging accuracy in renal cell carcinoma. BJU Int (2003) 91(1):37-40. doi:10.1046/j.1464-410X.2003.04017.x

128. Kates M, Lavery HJ, Brajtbord J, Samadi D, Palese MA. Decreasing rates of lymph node dissection during radical nephrectomy for renal cell carcinoma. Ann Surg Oncol (2012) 19(8):2693-9. doi:10.1245/s10434-012-2330-6

129. Middleton RG. Surgery for metastatic renal cell carcinoma. J Urol (1967) 97(6):973-7.

130. O’Dea MJ, Zincke H, Utz DC, Bernatz PE. The treatment of renal cell carcinoma with solitary metastasis. J Urol (1978) 120(5):540-2.

131. Kavolius JP, Mastorakos DP, Pavlovich C, Russo P, Burt ME, Brady MS. Resection of metastatic renal cell carcinoma. JClin Oncol (1998) 16(6): 2261-6. doi:10.1200/JCO.1998.16.6.2261

132. Alt AL, Boorjian SA, Lohse CM, Costello BA, Leibovich BC, Blute ML. Survival after complete surgical resection of multiple metastases from renal cell carcinoma. Cancer (2011) 117(13):2873-82. doi:10.1002/cncr.25836

133. Naito S, Kinoshita H, Kondo T, Shinohara N, Kasahara T, Saito K, et al. Prognostic factors of patients with metastatic renal cell carcinoma with removed metastases: a multicenter study of 556 patients. Urology (2013) 82(4):846-51. doi:10.1016/j.urology.2013.06.035

134. Daliani DD, Tannir NM, Papandreou CN, Wang X, Swisher S, Wood CG, et al. Prospective assessment of systemic therapy followed by surgical removal of metastases in selected patients with renal cell carcinoma. BJU Int (2009) 104(4):456-60. doi:10.1111/j.1464-410X.2009.08490.x

135. Dabestani S, Marconi L, Hofmann F, Stewart F, Lam TB, Canfield SE, et al. Local treatments for metastases of renal cell carcinoma: a systematic review. Lancet Oncol (2014) 15(12):e549-61. doi:10.1016/S1470-2045(14)70235-9

136. Zaid HB, Parker WP, Safdar NS, Gershman B, Erwin PJ, Murad MH, et al. Outcomes following complete surgical metastasectomy for patients with metastatic renal cell carcinoma: a systematic review and meta-analysis. J Urol (2017) 197(1):44-9. doi:10.1016/j.juro.2016.07.079

137. Pogrebniak HW, Haas G, Linehan WM, Rosenberg SA, Pass HI. Renal cell carcinoma: resection of solitary and multiple metastases. Ann Thorac Surg (1992) 54(1):33-8. doi:10.1016/0003-4975(92)91136-W

138. Sherry RM, Pass HI, Rosenberg SA, Yang JC. Surgical resection of metastatic renal cell carcinoma and melanoma after response to interleukin-2based immunotherapy. Cancer (1992) 69(7):1850-5. doi:10.1002/10970142(19920401)69:7<1850::AID-CNCR2820690729>3.0.CO;2-I

139. Sella A, Swanson DA, Ro JY, Putnam JB Jr, Amato RJ, Markowitz AB, et al. Surgery following response to interferon-alpha-based therapy for residual renal cell carcinoma. J Urol (1993) 149(1):19-21; discussion 21-2.

140. Krishnamurthi V, Novick AC, Bukowski RM. Efficacy of multimodality therapy in advanced renal cell carcinoma. Urology (1998) 51(6):933-7. doi:10.1016/S0090-4295(98)00033-8

141. Karam JA, Rini BI, Varella L, Garcia JA, Dreicer R, Choueiri TK, et al. Metastasectomy after targeted therapy in patients with advanced renal cell carcinoma. J Urol (2011) 185(2):439-44. doi:10.1016/j.juro.2010. 09.086

142. Bianchi M, Sun M, Jeldres C, Shariat SF, Trinh QD, Briganti A, et al. Distribution of metastatic sites in renal cell carcinoma: a population-based analysis. Ann Oncol (2012) 23(4):973-80. doi:10.1093/annonc/mdr362

143. Hofmann HS, Neef H, Krohe K, Andreev P, Silber RE. Prognostic factors and survival after pulmonary resection of metastatic renal cell carcinoma. Eur Urol (2005) 48(1):77-81; discussion 81-2. doi:10.1016/j.eururo.2005. 03.004

144. Zerbi A, Ortolano E, Balzano G, Borri A, Beneduce AA, Di Carlo V. Pancreatic metastasis from renal cell carcinoma: which patients benefit from surgical resection? Ann Surg Oncol (2008) 15(4):1161-8. doi:10.1245/ s10434-007-9782-0 
145. Jakubowski CD, Vertosick EA, Untch BR, Sjoberg D, Wei E, Palmer FL, et al. Complete metastasectomy for renal cell carcinoma: comparison of five solid organ sites. J Surg Oncol (2016) 114(3):375-9. doi:10.1002/jso.24327

146. Sandock DS, Seftel AD, Resnick MI. A new protocol for the followup of renal cell carcinoma based on pathological stage. J Urol (1995) 154(1):28-31. doi:10.1016/S0022-5347(01)67215-X

147. Levy DA, Slaton JW, Swanson DA, Dinney CP. Stage specific guidelines for surveillance after radical nephrectomy for local renal cell carcinoma. J Urol (1998) 159(4):1163-7. doi:10.1016/S0022-5347(01)63541-9

148. Ljungberg B, Alamdari FI, Rasmuson T, Roos G. Follow-up guidelines for nonmetastatic renal cell carcinoma based on the occurrence of metastases after radical nephrectomy. BJU Int (1999) 84(4):405-11. doi:10.1046/j.1464410x.1999.00202.x

149. Sheehan JP, Sun MH, Kondziolka D, Flickinger J, Lunsford LD. Radiosurgery in patients with renal cell carcinoma metastasis to the brain: long-term outcomes and prognostic factors influencing survival and local tumor control. J Neurosurg (2003) 98(2):342-9. doi:10.3171/jns.2003.98.2.0342

150. Shuch B, La Rochelle JC, Klatte T, Riggs SB, Liu W, Kabbinavar FF, et al. Brain metastasis from renal cell carcinoma: presentation, recurrence, and survival. Cancer (2008) 113(7):1641-8. doi:10.1002/cncr.23769

151. Nieder C, Spanne O, Nordoy T, Dalhaug A. Treatment of brain metastases from renal cell cancer. Urol Oncol (2011) 29(4):405-10. doi:10.1016/j. urolonc.2009.07.004

152. Ikushima H, Tokuuye K, Sumi M, Kagami Y, Murayama S, Ikeda H, et al. Fractionated stereotactic radiotherapy of brain metastases from renal cell carcinoma. Int J Radiat Oncol Biol Phys (2000) 48(5):1389-93. doi:10.1016/ S0360-3016(00)00804-X

153. Escudier B, Droz JP, Rolland F, Terrier-Lacombe MJ, Gravis G, Beuzeboc P, et al. Doxorubicin and ifosfamide in patients with metastatic sarcomatoid renal cell carcinoma: a phase II study of the Genitourinary Group of the French Federation of Cancer Centers. J Urol (2002) 168(3):959-61. doi:10.1097/01.ju.0000026902.77397.fd

154. Golshayan AR, George S, Heng DY, Elson P, Wood LS, Mekhail TM, et al. Metastatic sarcomatoid renal cell carcinoma treated with vascular endothelial growth factor-targeted therapy. J Clin Oncol (2009) 27(2):235-41. doi:10.1200/JCO.2008.18.0000
155. Haas NB, Lin X, Manola J, Pins M, Liu G, McDermott D, et al. A phase II trial of doxorubicin and gemcitabine in renal cell carcinoma with sarcomatoid features: ECOG 8802. Med Oncol (2012) 29(2):761-7. doi:10.1007/ s12032-011-9829-8

156. Thomas AZ, Adibi M, Slack RS, Borregales LD, Merrill MM, Tamboli P, et al. The role of metastasectomy in patients with renal cell carcinoma with sarcomatoid dedifferentiation: a matched controlled analysis. J Urol (2016) 196(3):678-84. doi:10.1016/j.juro.2016.03.144

157. Gerlinger M, Rowan AJ, Horswell S, Larkin J, Endesfelder D, Gronroos $\mathrm{E}$, et al. Intratumor heterogeneity and branched evolution revealed by multiregion sequencing. N Engl J Med (2012) 366(10):883-92. doi:10.1056/ NEJMoa1113205

158. Gofrit ON, Orevi M. Diagnostic challenges of kidney cancer: a systematic review of the role of positron emission tomography-computerized tomography. J Urol (2016) 196(3):648-57. doi:10.1016/j.juro.2016.02.2992

159. Manley BJ, Tennenbaum DM, Vertosick EA, Hsieh JJ, Sjoberg DD, Assel M, et al. The difficulty in selecting patients for cytoreductive nephrectomy: an evaluation of previously described predictive models. Urol Oncol (2017) 35(1): 35.e1-5. doi:10.1016/j.urolonc.2016.07.010

Conflict of Interest Statement: The authors declare that the research was conducted in the absence of any commercial or financial relationships that could be construed as a potential conflict of interest.

The reviewer, JB, and the handling editor declared their shared affiliation, and the handling editor states that the process nevertheless met the standards of a fair and objective review.

Copyright (C) 2017 Shinder, Rhee, Farrell, Farber, Stein, Jang and Singer. This is an open-access article distributed under the terms of the Creative Commons Attribution License (CC BY). The use, distribution or reproduction in other forums is permitted, provided the original author(s) or licensor are credited and that the original publication in this journal is cited, in accordance with accepted academic practice. No use, distribution or reproduction is permitted which does not comply with these terms. 